\title{
The morphogenetic capability and the viability of regenerants in micropropagated orchid hybrids infected with viral pathogens
}

\author{
Teresa Cybularz-Urban, Ewa Hanus-Fajerska \\ Department of Botany \\ Faculty of Horticulture, University of Agriculture in Kraków \\ 29 Listopada 54, 31-425 Kraków, Poland \\ e-mail: tcybularz@ogr.ar.krakow.pl; ehanus@ogr.ar.krakow.pl
}

Key words: Cattleya, micropropagation, acclimatization, CyMV, ORSV, viral infection

\begin{abstract}
The micropropagation efficiency of four interspecific Cattleya hybrids (clones: 69, 75, 149 and 150) infected with Cymbidium mosaic (CyMV) and Odontoglossum ringspot (ORSV) viruses was assessed. The aim of experiments was to evaluate with that model to what extent viral infection affects the morphogenesis in vitro in orchid hybrids of different origin. The effectiveness of plant material exposure to therapeutic levels of plant growth regulators supplied with media in order to suppress infection was also verified. The vitality of proliferating infected shoot cultures was limited, and the symptoms of senility were frequently observed. Regardless genotype of the studied clone, during acclimation to ex vitro conditions considerable losses become visible what indicates the necessity of testing the donor material for possible latent viral infections. Infection with CyMV and ORSV mostly persisted in every tested clone.
\end{abstract}




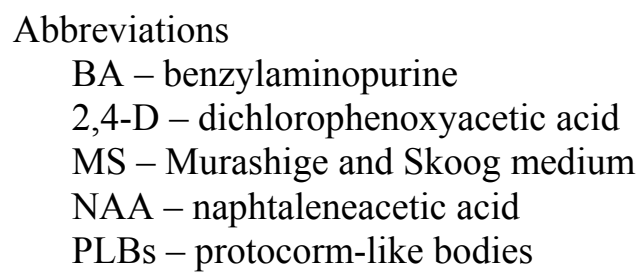

\section{INTRODUCTION}

Viral diseases affecting orchids were known since they had been cultivated in greenhouse conditions during Victorian times, but it was not before 1950 that those viruses were properly characterized. Jensen (1951), and at the same year Jensen and Gold (1951) described Cymbidium mosaic virus (CyMV) and Odontoglossum ringspot virus (ORSV). Contemporary there have been identified numerous viruses infecting orchids, nevertheless CyMV and ORSV are commonly diagnosed in most genera belonging to the family Orchidaceae brought under cultivation. As a result Cymbidium mosaic and Odontoglossum ringspot viruses are considered to be a significant problem for horticulture production (Zettler et al. 1990, Hu et al. 1994, Geraci 1996, Wannakrairoj et al. 2000, Siverio-Nunez 2001, Kroteyeva et al. 2002, Barcial and Bajet 2003, Sherpa et al. 2003, Grisoni et al. 2004, Choi et al. 2004, Novalinskiene et al. 2005, Khentry et al. 2006).

Orchids are propagated both from seeds and vegetatively, but the process is slow. Application of various methods of micropropagation are principal approach for rapid multiplication of precious varieties and commercial hybrid clones. Numerous techniques, including both meristem and shoot tips culture (Reinert and Mohr 1967, Champagnat and Morel 1969, Mauro 1994, Torres and Mogollon 2000), leaf and root tissue culture (Champagnat et al. 1970, Pindel and Miczyński 1996, Murthy and Pyati 2001, Chen et al. 2004), culture of stalk bulbs, flowers and capsules (Pindel and Pindel 2004, Pindel 2007) allow for wide distribution of plant material. The introduction of in vitro techniques to the production of cultivated orchids allowed to shorten the time and expenses needed to obtain marketable plant material in comparison to traditional propagation means, but simultaneously had been the casual reason of widespread all over the world of viral diseases (Wisler 1989, Zettler et al. 1990). This is the rationale why, apart from numerous known literature data on micropropagation of pathogen-free orchids, it could be interesting to compare the organogenetic capabilities of virus-infected mericlones and the viability of regenerated plantlets. In presented investigations we focused on evaluation to what extend the mixed virus infection affect the multiplication of orchid hybrids of different origin. The further purpose was to estimate what are the possibilities to cure infected material from CyMV and from ORSV infection when primary explanted apical dome measured about $1 \mathrm{~mm}^{3}$ in size. 


\section{MATERIAL AND METHODS}

Interspecific hybrids of South American genus Cattleya: Cattleya waltersiana $\times$ C. marone (clone 149), Cattleya waltersiana $\times$ C. schönbrunennsis (clone 69), Cattleya bonanse $\times$ C. schönbrunnensis (clone 75) and Cattleya labiata $\times$ C. marone (clone 150), obtained from the orchid collection of the Jagiellonian University Botanical Garden were studied. Respective clones were systemically coinfected with CyMV and ORSV. The viruses were detected in tissues of donor plants using direct double-antibody-sandwich enzyme-linked immunosorbent assay (DAS-ELISA) as described by Clark and Adams (1977). Afterwards in regenerated shoots of each clone infectivity of tissue samples were demonstrated on Cassia occidentalis L., Chenopodium amaranticolor Costa Reyn, Ch. quinoa Willd., Gomphrena globosa L., Nicotiana glutinosa L., N. tabacum L. 'Xanthi', Tetragonia expansa Murr., used as indicators of CyMV and ORSV infection (Wisler 1989).

Cultures were initiated in June 2002, after surface sterilization of shoots with $0.1 \% \mathrm{v} / \mathrm{v}$ solution of mercuric chloride for $1 \mathrm{~min}$. Inititial explants were colorless meristematic dome excised from buds under stereoscopic microscope. $25 \mathrm{ml}$ of MS salts and vitamins supplemented with $2.0 \mathrm{mg} \mathrm{dm}^{-3}$ adenine sulphate, $9.7 \mathrm{mg} \mathrm{dm}^{-3}$ ascorbic acid, $0.5 \mathrm{mg} \mathrm{dm}^{-3}$ zeatine, $4.95 \mathrm{mg} \mathrm{dm}^{-3} \mathrm{BA}, 1.0 \mathrm{mg} \mathrm{dm}^{-3} \mathrm{NAA}$ and $3 \%$ $(\mathrm{w} / \mathrm{v})$ sucrose, adjusted to $\mathrm{pH} 5.5$, were poured to $100 \mathrm{ml}$ Erlenmeyer flasks. Ten aseptic meristems, about $1 \mathrm{~mm}^{3}$ in size, were placed into liquid medium. Shoots about $20 \mathrm{~mm}$ high, obtained from meristematic explants, were cultured onto proliferation medium solidified with $0.8 \%(\mathrm{w} / \mathrm{v})$ agar (Bacto Agar, DIFCO), and additionally supplemented with $0.2 \mathrm{mg} \mathrm{dm}^{-3}$ zeatine and $0.125 \mathrm{mg} \mathrm{dm}^{-3}$ 2,4-D. Culture flasks, $350 \mathrm{~cm}^{3}$ capacity, containing $50 \mathrm{~cm}^{3}$ of medium were employed for the subculture during micropropagation stage. Plant material was transferred every seven weeks onto appropriate fresh media. The culture environment was maintained at $25 \pm 2{ }^{\circ} \mathrm{C}$, under continuous/16-h light under cool-white fluorescent light and 8-h dark period per day, and with light intensity of $80 \mu \mathrm{molm}^{-2} \mathrm{~s}^{-1}$ at $70 \%$ relative humidity.

The cultures were carefully observed during each cultivation passage. Thirty plantlets were cultured per replication and fifteen replications were carried out for each tested clone. In the end of second passage in the representative samples the number and length of regenerated adventitious shoots and aerial roots were noted and measured, and their fresh and air dry weight were evaluated. The experiment was repeated twice and the results were subjected to STATISTICA 6.1, ANOVA analysis. The significance of differences between means was assessed with a posteriori Fisher's test at $\mathrm{p}=0.05$. 


\section{RESULTS AND DISCUSSION}

The regeneration of PLBs was observed onto aseptically isolated meristematic domes isolated from each hybrid clone. Afterwards, when vegetative organs have been regenerated from PLBs, regenerated shoots were transferred to the proliferation medium in order to multiply obtained material. The course of the proliferation of studied clones expressed in terms of both fresh and dry weight and in length of shoots regenerated after three months of culture was different in a case of respective genotypes (Table 1). Shoots of Cattleya waltersiana $\times$ C. marrone coinfected with both viruses reached the biggest dimensions, with the mean shoot length of $21 \mathrm{~mm}$, whereas in cultures of Cattleya labiata $\times$ C. marone there were regenerated shoots only $8 \mathrm{~mm}$ in length. The vitality of micropropagated infected material was rather limited, what was observed as drying up of lower leaves and particular aerial roots (Figs 1 and 3 ). The multiply coefficient was fluctuating from 5.1 in Cattleya waltersiana $\times$ C. schönbrunennsis to 10.3 in Cattleya labiata $\times C$. marone. Unfortunately, all donor plants of these precious hybrids were infected, and it was impossible to obtain healthy control material without future prolonged therapy treatment. In the matter of effectiveness of root regeneration in studied orchid clones, in Cattleya bonanse $\times$ C. schönbrunnensis cultures roots were easily initiated (6.2 per shoot) and smoothly elongated, reaching the mean length $11 \mathrm{~mm}$ (Table 1). It can be also seen that comparable to clone 75 in terms of longitude were roots regenerated in Cattleya waltersiana $\times$ C. marone culture, but their number was significantly lower (Table 1 and Fig. 2).

Table 1. The morphogenetic potential of coinfected with cymbidium mosaic and odontoglossum ringspot viruses mericlones of four Cattleya hybrids

\begin{tabular}{lcccc}
\hline Feature & $\begin{array}{c}\text { C. waltersiana } \times \text { C. } \\
\text { marone } \\
\text { (clone 149) }\end{array}$ & $\begin{array}{c}\text { C. waltersiana } \times \\
\text { C. schönbrunnensis } \\
\text { (clone 69) }\end{array}$ & $\begin{array}{c}\text { C. bonansa } \times \\
\text { C. shönbrunnensis } \\
\text { (clone 75) }\end{array}$ & $\begin{array}{c}\text { C. labiata } \times \\
\text { C. marone } \\
\text { (clone 150) }\end{array}$ \\
\hline Shoot number & $7.5 \mathrm{a}^{*}$ & $5.1 \mathrm{a}$ & $7.1 \mathrm{a}$ & $10.3 \mathrm{~b}$ \\
$\begin{array}{l}\text { Shoot length } \\
(\mathrm{mm})\end{array}$ & $21 \mathrm{c}$ & $15 \mathrm{~b}$ & $15 \mathrm{~b}$ & $8.0 \mathrm{a}$ \\
$\begin{array}{l}\text { Aerial roots } \\
\text { number }\end{array}$ & $3.8 \mathrm{a}$ & $5.2 \mathrm{ab}$ & $6.2 \mathrm{~b}$ & $4.2 \mathrm{a}$ \\
$\begin{array}{l}\text { Root length } \\
\text { (mm) }\end{array}$ & $11 \mathrm{~b}$ & $7.0 \mathrm{a}$ & $11 \mathrm{~b}$ & $7.0 \mathrm{a}$ \\
$\begin{array}{l}\text { Fresh weight } \\
(\mathrm{mg})\end{array}$ & $293 \mathrm{ab}$ & $257 \mathrm{a}$ & $369 \mathrm{bc}$ & $408 \mathrm{c}$ \\
$\begin{array}{l}\text { Dry weight } \\
(\mathrm{mg})\end{array}$ & $26 \mathrm{a}$ & $24 \mathrm{a}$ & $31.3 \mathrm{ab}$ & $33 \mathrm{~b}$ \\
\hline
\end{tabular}

*values followed by the same letter within column do not significantly differ at $\mathrm{p}=0.05$ 
The survival of material regenerated from infected cultures was distinctly limited. During acclimatization to ex vitro conditions there were observed considerable losses, regardless genotype of the studied clone (Fig. 4). The tests conducted in regenerants revealed that among plants regenerated from in vitro cultures a part of material was infected only with ORSV (27\% in clone $69-$ Cattleya waltersiana $\times$ C. schönbrunennsis and $18 \%$ in clone $75-$ Cattleya bonanse $\times$ C. schönbrunnensis). It is worth underlining that in whole material regenerated from cultures of Cattleya waltersiana $\times C$. marone and Cattleya labiata $\times C$. marone the mixed infection with ORSV and CyMV persisted. In microcuttings of Cattleya waltersiana $\times$ C. schönbrunennsis and Cattleya bonanse $\times$ C. schönbrunnensis roots were easily obtained, what can be connected with decreasing of the viral infection level in tissues of those hybrids (Hanus-Fajerska 1999, Freitas-Asuta 2003).

There have been some particular reports on cell and tissue propagation of epiphytic orchids, as they were considered as an interesting model for plant development and metabolic studies, but to the best of our knowledge there is no such published data dealing with infected material (Peres and Kerbauy 1999, Majerowicz et al. 2000, Nge et al. 2006). In initial stages of in vitro cultures it was impossible to perceive any signs of degeneration in virus infected material, no matter of genotype used in the experiment. However, following prolonged period of cultivation the vitality of cultures was suddenly lost, and what is more, on the stage of acclimatization numerous plants died. It clearly indicates the necessity of testing not only the donor material in respect of possible latent viral infections, but micropropagated cultures as well, what is consistent with findings of Kroteyeva and coworkers (2002). The separate problem is probability of spontaneous recovery from viral infection in the course of prolonged cultivation in vitro on media supplemented with relatively high levels of plant growth regulators, what was studied by present authors in Cattleya schönbrunennsis $\times$ C. leopoldii gutata cultures (Cybularz-Urban and Hanus-Fajerska 2006). Working with material of another origin, once again it was only attainable to eradicate the more labile Cymbidium mosaic virus in this way. Odontoglossum mosaic persisted (Figs 5a and b), even when in the micropropagation stage dichlorophenoxyacetic acid (known for high mutation rates) was included. Perhaps such method had been effective in eliminating viral RNA from infected vegetative tissues of $C$. waltersiana $\times C$. schönbrunennsis and Cattleya bonanse $\times$ C. schönbrunnensis (Ishii 1974, Albouy et al. 1988, Freitas-Astua and Rezende 1988, Lim et al. 1993, Freitas-Astua 2003, Jiang et al. 2005). Further studies are needed to elucidate this complex phenomenon. 

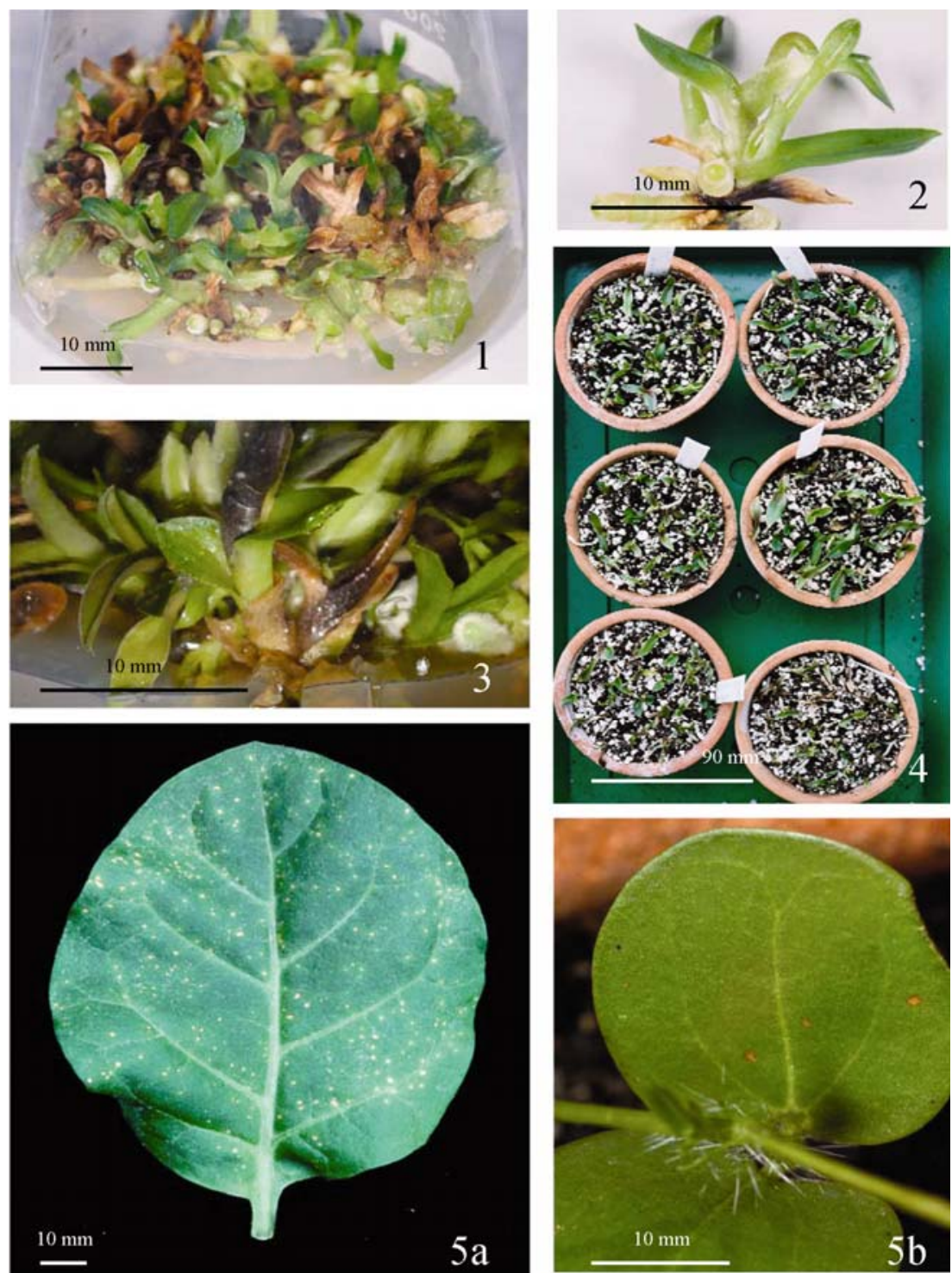

Fig. 1. Clone 149 of Cattleya waltersiana $\times$ C. marone cultivated in vitro on modified MS medium with addition of $0.2 \mathrm{mg} \mathrm{dm}^{-3}$ zeatine and $0.125 \mathrm{mg} \mathrm{dm}^{-3} 2,4-\mathrm{D}$

Fig. 2. Single clone 149 Cattleya waltersiana $\times$ C. marone plantlet regenerated from shoot cultures during second passage

Fig. 3. Clone 150 of Cattleya labiata $\times$ C. marone cultivated on modified MS medium supplemented with $0.2 \mathrm{mg} \mathrm{dm}^{-3}$ zeatine and $0.125 \mathrm{mg} \mathrm{dm}^{-3} 2,4-\mathrm{D}$

Fig. 4. Regenerated plantlets after transplanting to pots and transferred to ex vitro conditions

Fig. 5. Symptoms of local infection on leaves of indicator plants inoculated with isolate from regenerated plants (a) Nicotiana tabacum L. 'Xanthi' nc (b) Cassia occidentalis L. 


\section{REFERENCES}

Albouy J., FlouZat C., KusiaK C., TRONChet M., 1988. Eradication of orchid viruses by chemotherapy from in vitro cultures of Cymbidium. Acta Hort. 234: 413-420.

BARCIAL M.P., BAJET N.B., 2003.Geographical distribution, detection and symptoms of virus infection in orchids. Regional Research and Development Symposium, Philippines, PCARRD-Highlights-2002: 83-84.

Champagnat M., Morel G., 1969. Multiplication vegetative des Cattleya a partir de bourgeons cultivés in vitro. Soc. Bot. Fr. Mém. 116: 111-132.

Champagnat M., Morel G., Mounetou B., 1970. La multiplication vegetative des Cattleya a partir de jeunes feuilles cultivées aseptiquement in vitro. Ann. Sci. Nat. Bot. Sér. 12, 11: 97-114.

Chen T.Y., Chen J.T., ChANG W.C., 2004. Plant regeneration through direct shoot bud formation from leaf cultures of Paphiopedilum orchids. In vitro Cell. Dev. Biol., Plant 76: 11-15.

ChOI S.H., Wong S.M., RYU K.H., 2004. Comparison of coat protein genes of Cymbidium mosaic virus and Odontoglossum ringspot virus from Phalaenopsis and Cymbidium in Korea. Proc. 11 ${ }^{\text {th }}$ Intl. Sym. On Virus Diseases of Ornamental Plants, March 09-14, Taiwan.

ClaRK M.F., ADAMS S.M., 1977. Characteristics of the microplate method of enzyme-linked immunosorbent assay for the detection of plant viruses. J. Gen. Virol. 34: 457-483.

CybularZ-URBAN T., HANUS-FAJERSKA E., 2006. Therapeutic effect of cytokinin sequence application on virus-infected Cattleya tissue cultures. Acta Biol. Cracov. Ser. Bot. 48: 27-32.

Freitas-Astua J., 2003. Orchid viruses. American Orchid Soc. Bull. 75: 578-580.

FREITAS-ASTUA J., REZENDE J.A.M., 1998. Odontoglossum virus-free Cymbidium obtained through meristem tip chemotherapy. Fitopatologia Brasileira 23(2): 158-160.

GERACI R.B., 1996. Major viruses affecting orchids. Am. Orchid Soc. Bull. 65: 836-843.

Grisoni M., Davidson F., Hyrondelle C., Farreyrol K., Caruana M.L., PEARSON M., 2004. Nature, incidence, and symptomathology of viruses infecting Vanilla thaitanensis in French Polynesia. Plant Dis. 88: 119-124. 
HANUS-FAJERSKA E., 1999. Rooting and acclimatization of micropropagated virusinfected tomato (Lycopersicon esculentum Mill.) plants. Zesz. Probl. Post. Nauk Roln. 469: 555-561.

HU J.S., Ferreira S., WANG M., 1994. Movement and inactivation of Cymbidium mosaic and Odontoglossum ringspot viruses. Plant Dis. 78: 464-448.

JENSEN D.D., 1951. Mosaic or black streak disease of Cymbidium orchids. Phytopath. 41: 401- 414.

JENSEN D.D., GOLD A.H., 1951. A virus ringspot of Odontoglossum orchid: symptoms, transmissions and electron microscopy. Phytopath. 41: 648-653.

JiANG L., ZHANG M.T., CHEN Z.X., MA G.H., 2005. Eradiation of CymMV from tissue cultures of Cymbidium sinense with chemotherapy. Acta Hort. Sin. 32(6): 1056-1060.

ISHII M., 1974. Partial elimination of virus from doubly infected orchids by meristem explant culture. Acta Hort. 36: 229-233.

Khentry Y., Paradornuwat A., Tantiwiwat S., Phransiri S., ThaVeechai N., 2006. Incidence of Cymbidium mosaic virus and Odontoglossum ringpot virus in Dendrobium spp. in Thailand. Crop Prot. 25(9): 926-932.

Kroteyeva A.V., Polischuk V.P., Brysov A.S., LAVERENTYeVA A.N., BOyKo A.L., 2002. Necessity for virus control on different stages of Orchidaceae plant's introduction. In: Biotechnology approaches for exploitation and preservation of plant resources. Proc. Intl. Sym. Yalta, Ukraine, May 26-31, Byulleten' Gosudarstvennogo Nikitskogo Botanicheskogo Sada 86: 47-49.

LIM S.T., WONG S.M., GoH C.J., 1993. Elimination of Cymbidium mosaic virus and Odotoglossum ringspot virus from orchids by meristem culture and thin section culture with chemotherapy. Ann. Appl. Biol. 122: 289-97.

Majerowicz N., Kerbauy G.B., Nievola C.C., SuZuKi R.M., 2000. Growth and nitrogen metabolism of Catasetum fimbriatum (Orchidaceae) with different nitrogen sources. Environ. Exp. Bot. 44: 195-206.

MAURO M., 1994. Influence of benzylaminopurine and alpha naphthalenecetic acid on multiplication and biomass production of Cattleya aurantiaca shoot explants. Lindleyana West Palm Beach 9: 169-173.

MurThy H.N., Pyati A.N., 2001. Micropropagation of Arides maculosum Lindl. (Orchideaceae). In vitro Cell. Dev. Biol., Plant 37: 223-226.

Novalinskiene M., Raugalas J., Samuitiene M., 2005. Identification of viruses affecting orchids (Cymbidium Sw.). Biologija 2: 29-34.

Nge K.L., New N., Chandrkrachang S., Stenens W.F., 2006. Chitosan as a growth stimulator in orchid tissue culture. Plant Sci. 170: 1185-1190. 
PERES L.E.P., KerBAUY G.B., 1999. High cytokinin accumulation following root tip excision changes the endogenous auxin-to-cytokinin ratio during root-toshoot conversion in Catasetum fimbriatum Lindl. (Orchidaceae). Plant Cell Rep. 18: 1002-1006.

PINDEL A., 2007. The role of activated charcoal and benzylaminopurine in micropropagation of Cypripedium calceolus L. Zesz. Probl. Post. Nauk Roln. 523: $163-169$.

PINDEL A., MiCZYŃSKI K., 1996. Regeneration of Cymbidium orchids from leaf and root explants. Folia Hort. 8/2: 95-105.

PINDEL A., PINDEL Z., 2004. Initiation of in vitro cultures of chosen endangered European species of orchids. Folia Hort. 16/2: 111-117.

REINERT A., MoHR H.C., 1967. Propagation by tissue culture of lateral bud meristem. Proc. Am. Soc. Hort. Sci. 91: 664-661.

SHERPA A.R., HALlan V., RAM R., ViJ S.P., PATHAK P., GARG I. D., ZAIDI A.A., 2003. First report of Cymbidium mosaic virus (CymMV) orchids from Sikim, India. Plant Pathol. 52: 788.

SIVERIO-NUNEZ A., 2001. Detection and prevention of Cymbidium mosaic virus (CyMV) and Odontoglossum ringspot virus (ORSV), in orchids of Cymbidium genus in Tenerife Island, Canary Islands, Spain. Agricola - Vergel 237: 493495.

TORRes J., Mogollon N., 2000. Micropropagación de Cattleya mossiae Parker ex Hook. mediante brotación axilar inducida por tidiazurón. Bioagro 12(1): 10-14.

WannakrairoJ S., PilueK C., KLadPan S., 2000. Final report: Impacts and Impact Reduction of Virus on Cut Flower Orchid Production. Research Council of Thailand, Bangkok.

WISLER G.C., 1989. How to control orchid viruses: The complete guidebook. Maupin House Publishers.

Zettler F.W., Ko N.J., Wisler G.C., Elliott M.S, Wong S.M., 1990. Virus of orchids and their control. Plant Dis. 74: 621-626. 


\section{MOŻLIWOŚCI MORFOGENETYCZNE I ŻYWOTNOŚĆ REGENERANTÓW MIKROROZMNAŻANYCH MIESZAŃCÓW CATTLEYA PORAŻONYCH PATOGENAMI WIRUSOWYMI}

Streszczenie: Oceniano efektywność mikrorozmnażania czterech międzygatunkowych mieszańców Cattleya zainfekowanych kompleksem wirusa mozaiki cymbidium (CyMV) i wirusa pierścieniowej plamistości odontoglossum (ORSV). Celem przeprowadzonych badań było ustalenie przy użyciu opisanego modelu do jakiego stopnia infekcja wirusowa może wywierać wpływ na procesy morfogenetyczne in vitro w materiale mieszańcowym o różnym pochodzeniu oraz sprawdzenie potencjalnego działania terapeutycznego wysokich dawek regulatorów wzrostu i rozwoju aplikowanych w pożywkach. Proliferujące kultury pędowe często wykazywały objawy starzenia. Niezależnie od genotypu ocenianych klonów w trakcie adaptacji do warunków ex vitro zaobserwowano duże wypady roślin. Większość uzyskanych regenerantów była nadal porażona CyMV i ORSV. $\mathrm{Z}$ uwagi na możliwość wystąpienia infekcji utajonej zaleca się testowanie roślin donorowych na obecność wirusów. 